\title{
Vitamin D and melanoma incidence and mortality
}

\author{
Marianne Berwick and Eszter O. Erdei \\ Division of Epidemiology, Biostatistics and Preventive Medicine, Department of Internal Medicine, \\ University of New Mexico Cancer Center, Albuquerque, NM, USA
}

\section{Summary}

The role of vitamin $\mathrm{D}$ (25-OH-D, or 25-hydroxyvitamin $\mathrm{D}$ ) and its potential confounders in relationship to melanoma risk and mortality is discussed. The paradox that ultraviolet radiation (UVR) exposure is the major environmental risk factor for melanoma etiology as well as a major source of vitamin $\mathrm{D}$ might be explained by viewing vitamin D levels as the result of a healthy lifestyle rather than a cause of health.

\section{Keywords}

melanoma; incidence; mortality; ultraviolet radiation

\section{Introduction}

The relationship of serum levels and genetic factors of vitamin D to melanoma risk and melanoma mortality is today unclear. It is not yet known whether vitamin D measured through genetic factors or serum levels is causal, whether it leads to better melanoma outcomes, or whether it is the result of a healthier lifestyle (Brock et al., 2010) because vitamin D levels are often higher in fitter, leaner, more physically active people. The data in this perspective are presented to demonstrate the current state of the art in relationship to vitamin D and melanoma risk and melanoma mortality. A distinction should be made between serum vitamin D levels and 'risk' for developing melanoma and serum vitamin D levels and 'outcome', that is, survival with melanoma. Few cohort studies have prospectively measured serum vitamin $\mathrm{D}$ prior to the development of melanoma because melanoma is actually a fairly rare outcome. Thus, most studies have measured serum vitamin D close to the time of diagnosis as a proxy for prior levels. In fact, several studies that have measured individual stability in vitamin D levels over time find that a one-time measure of serum vitamin D is a fair approximation of future levels (e.g., Hofmann et al., 2010; Jorde et al., 2010). Several additional studies have measured serum vitamin D at the time of diagnosis and followed patients for survival (Newton-Bishop et al., 2009). These are solid studies. However, neither type of study actually supports causality, but, in fact, can also be used as examples of 'reverse' causality, where the measure is actually an 'outcome' itself.

\section{Basic science studies (preclinical studies) in relationship to melanoma}

The backdrop of basic science studies in relationship to vitamin D and melanoma is important for human studies. As early as 1981, Colston et al. (1981) published in vitro studies of vitamin D in melanoma cell lines and melanoma tumors grown in rats. They 
demonstrated the first observation of an antiproliferative effect of vitamin D. Others have demonstrated inhibition of invasiveness (Yudoh et al., 1999) and inhibition of cancer cell growth (Danielsson et al., 1998; Evans et al., 1996; Frampton et al., 1983) to show differential apoptotic response of human melanoma cells. Mason et al., 1988 demonstrated that differentiation could be induced by vitamin D. Then in 2010 , this group demonstrated a potential role for vitamin D in reducing DNA damage and increasing DNA repair (Drané et al., 2004). Additionally, important for melanoma etiology is that the vitamin D receptor is inducible by UVB in intact skin (Demetriou et al., 2012).

\section{Types of UV radiation and melanoma risk}

UV radiation has long been associated with the etiology of melanoma - previously focus had been primarily on UVB radiation (280-320 $\mathrm{nm}$ ) but with the realization that tanning beds are carcinogenic, and other lines of evidence (Autier et al., 2011; Wang et al., 2001), there is a focus on both UVA $(320-400 \mathrm{~nm})$ and UVB. UVB radiation induces DNA damage in the form of mutations and cyclobutane dimers and is 'short wave'. There is a very large body of evidence that UVB is an important risk factor for melanoma, and so, it will not be covered in this perspective. However, specific UV-B wavelengths (290-315) cause a precursor in the skin (7-dehydrocholesterol) to form vitamin $\mathrm{D}_{3}$ (Glerup et al., 2000).

Tanning beds emit spectra similar to sun in the UVB (280-320) although that varies with the specific equipment. However, they often reach values 10-15 times higher in the UVA (Gerber et al., 2002). Effective irradiance corresponds to UV index of 13 - much higher than UV index of 8.5 at solar noon in the summer at intermediate latitudes. Similar data were reported from Norway (Nilsen et al., 2012). Tanning beds have been promulgated as safe tanning and also a good source of vitamin D. That tanning using sunbeds provides vitamin D has been supported by Thieden et al. (2008), who showed dose-dependent increases in serum vitamin D that plateaued relatively quickly. Unfortunately, this group also noted side effects such as erythemal and polymorphic light eruption. In Norway, Moan et al. (2009) reported that tanning beds raised serum vitamin D levels from winter to summer levels. Unfortunately, there is now strong evidence that use of tanning beds is associated with melanoma risk, and in one study with melanoma mortality. In 2007, IARC conducted a systematic review on the association between sunbeds and melanoma and found that at that time, there was inconsistent but potentially important evidence that sunbed exposures, particularly among those who were first exposed prior to the age of 35, were associated with melanoma risk (IARC, 2007). The strongest evidence to date is from Minnesota. In 2010, Lazovich et al., found strong and statistically significant increases in risk - as high as an odds ratio of 4.44 (95\% confidence interval $=2.45-8.02)$ in those tanning beds that were primarily UVA emitting.

\section{UV radiation and serum vitamin D levels}

UVB radiation has been considered the major source of serum vitamin D. Unfortunately, many studies have used proxies for measured UVB - either latitude or time in recreational activities. Both have severe shortcomings as proxies for measured UVB. Careful research, using accurate measures of solar UV exposure using a UV dosimeter, shows that UVB may account for as much as 30-40\% of the variation in one's serum vitamin D level (Thieden et al., 2006). Accurate dosage of UVB has not, until recently, been measured in relationship to a change in serum vitamin D levels. Bogh et al. (2011) has been carrying out a series of experiments to estimate the amount of UV that is necessary to increase serum vitamin D levels. In a randomized controlled trial, he was able to expose different amounts of skin to $0.75,15$, and 3.0 standard erythemal doses of UVB. Significant UVB responses correlated with 6 and $12 \%$ exposure but not with $24 \%$ where saturation was achieved. A striking 
finding is the importance of individual baseline vitamin $\mathrm{D}$ in determining the increase in serum vitamin D with UVB dose. Additionally, they find that 'more' is not necessarily 'better', so that a small surface area exposed with a small UVB dose resulted in significant changes in vitamin D (Bogh et al., 2011). When comparing results from many studies, it is critical to note that there is poor agreement between various assays for serum vitamin D (Lips et al., 1999; Nowak et al., 2011) and that this lack of agreement is likely a significant and often overlooked issue when comparing studies. Recent efforts to standardize measures using a specific protocol and external quality assurance materials have demonstrated that reliable data can be obtained (Sempos et al., 2012).

\section{Dietary vitamin $D$, supplements and melanoma risk}

Obvious alternatives to UV exposure are diet and supplements. Diet is generally a poor source of vitamin D, with the most effective dietary source of vitamin D fatty fish. Few studies have evaluated dietary vitamin $\mathrm{D}$, supplemental vitamin $\mathrm{D}$ with melanoma risk or mortality. Those few studies that have evaluated diet and melanoma risk have varying results. Weinstock et al. (1992) evaluated vitamin D intake and found no association with melanoma risk among 165 cases and 209 healthy controls. Millen et al. (2004) showed that dietary vitamin $\mathrm{D}$ intake was associated with a decrease in melanoma risk among 502 patients with melanoma and 565 healthy controls. Vinceti et al. (2011) evaluated 380 cases and 719 controls in Italy where the average daily intake of vitamin D from foodstuffs is low. They found an inverse association between dietary vitamin D and melanoma risk, which was stronger among males and older individuals. In two much larger studies, there was no evidence of an effect of vitamin D intake and risk for melanoma. In the Women's Health Initiative, there was no association between melanoma risk and treatment with $400 \mathrm{IU}$ vitamin D and $1000 \mathrm{mg}$ calcium among 176 cases of melanoma in 36282 women (Tang et al., 2011). In the VitaL cohort study (Asgari et al., 2009), where 68611 participants reported dietary and supplemental vitamin $\mathrm{D}$, there was no association of vitamin D intake with melanoma risk among the 455 incident melanomas. At this time, there is inadequate evidence to suggest vitamin D supplementation decreases risk for melanoma.

\section{Serum vitamin D and melanoma risk}

The question remains as to how serum vitamin $\mathrm{D}$ levels relate to risk for melanoma. Reichrath and Quering (2004) evaluated serum levels of vitamin D in 14 patients with melanoma and found no evidence for reduced 25-hydroxyvitamin D. Major et al. (2012), in a much larger study, found no association between serum vitamin D levels and risk for melanoma among 368 Finnish male smokers who had participated in the Alpha-Tocopherol Beta-Carotene Cancer Prevention study. Using an algorithm to predict serum vitamin D levels, developed with data from the Health Professionals Follow-Up Study, Giovannucci et al. (2006) quantitated the relationship of dietary and supplementary vitamin $\mathrm{D}$, skin pigmentation, adiposity, geographic residence and leisure-time physical activity with serum levels of vitamin D among 1095 men. They then applied this algorithm to the 47800 men in the cohort. When they evaluated cancer risk and mortality in relationship to predicted serum vitamin $\mathrm{D}$, they found the expected increase in melanoma risk nonsignificantly associated with predicted serum vitamin D. Others have developed similar algorithms using slightly different variables (i.e., Davies et al., 2011). Several studies have found that deeper Breslow thickness (Randerson-Moor et al., 2009) or higher stage (Nürnberg et al., 2009) was associated with lower serum vitamin D, or both (Gambichler et al., 2012).

\section{Sun exposure and melanoma mortality}

Although a number of studies have evaluated ecological associations between latitude and melanoma mortality, only a few have looked at individual-level data and melanoma 
mortality. In a Connecticut population-based study of 650 melanoma cases followed for an average of $5 \mathrm{yr}$, Berwick et al. (2005) reported that several measures of UVR prior to the diagnosis of melanoma were inversely associated with mortality from melanoma.

Subsequently, Rosso et al. (2008) in a European study of 260 patients with melanoma found that melanoma patients with more sunny vacations prior to diagnosis had better survival. Many studies have evaluated mortality by latitude. For example, most recently, Shipman et al. (2011) evaluated average annual sunlight hours in 36 European cities and compared these with melanoma rates to find lower melanoma mortality in sunnier European countries.

\section{Serum vitamin D and melanoma survival}

Randerson-Moor et al. (2009) showed that serum 25-hydroxyvitamin D3 levels were inversely correlated with tumor thickness among 941 patients with melanoma although there was no difference in serum vitamin $\mathrm{D}$ levels between healthy controls $(\mathrm{n}=114)$ and the patients. The significant association between higher serum vitamin $\mathrm{D}$ levels and thinner Breslow thickness may indicate some functionality of serum vitamin $\mathrm{D}$ in containing lesions. In their retrospective analysis of 250 patients with melanoma, Newton-Bishop et al. (2009) reported that those who did not relapse had nonsignificantly increased levels of serum vitamin $\mathrm{D}(49 \mathrm{nM}$ versus $46 \mathrm{nM})$. Then, in the prospective analysis of 872 patients with melanoma followed for a median of $4.7 \mathrm{yr}$, they demonstrated a survival advantage among those who had higher serum vitamin D levels. Those 872 prospectively followed had higher vitamin $\mathrm{D}$ levels and lower Breslow thickness at diagnosis $(\mathrm{P}=0.002)$ and were less likely to relapse with melanoma or die from any cause. A German study found similar results (Nürnberg et al., 2009). Serum $25(\mathrm{OH})$ D levels were significantly reduced in patients with stage IV melanoma as compared to patients with stage I melanoma $(\mathrm{P}=0.006)$, previous sun exposure was strongly associated with serum vitamin D levels and other indicators, such as Breslow thickness and time to metastasis were nonsignificantly associated with serum vitamin D levels.

\section{Genetic factors (VDR) and melanoma risk}

Multiple papers have summarized the association between single-nucleotide polymorphisms in the vitamin D receptor and risk for melanoma, using meta-analysis techniques or simple reviews (Denzer et al., 2011; Egan, 2009; Gandini et al., 2009; Mocellin and Nitti, 2008; Orlow et al., 2012; Ward et al., 2012). An important systematic meta-analysis of multiple genetic association studies in melanoma (Chatzinasiou et al., 2011) reported that the VDR polymorphism rs 1544410 , usually referred to as $B s m I$, was potentially biased as the summary odds ratio of $<1.15$ can be dissipated by even relatively small biases in metaanalyses of published data. Thus, the credibility of the VDR genotypes as having significant risk for melanoma is still uncertain. This can be clearly seen in Table 1 that summarizes the most commonly genotyped polymorphisms in the VDR gene: FokI (rs2228570), BsmI (rs1544410), TaqI(rs731236), $A-1012 G$ (also known as EcoRV) (rs4516035), and $C d \times 2$ (rs1156820). For example, the estimates for melanoma risk for FokI range from 0.81 to 1.90, with only one study being statistically significant (Randerson-Moor, 2009). Most SNPs do not demonstrate independent effects, although Orlow et al. (2012) found that among 38 VDR SNPs, eight in the promoter, coding and 3' regions were associated with modest, but statistically significant increased or decreased risk for melanoma. This was in a very large study of more than 3000 population-based individuals with melanoma and so might be considered representative of the role of the SNPs in melanoma risk and supports an important role for the VDR in melanoma risk. In an extension of SNP evaluation into analysis of gene-environment interaction, Mandelcorn-Monson et al. (2011) found an interaction between a VDR SNP and sun exposure history that increased the risk for melanoma. 


\section{Potential modifying factors: pigmentation, body mass index, and sunscreen}

A major issue in assessing vitamin D levels is the number of potential modifying factors that could either be confounders or mediators in the association between serum vitamin D and disease. The major potential confounders for melanoma are pigmentary characteristics, body mass index (BMI) and sunscreens. Of these, the strongest evidence is that those with a higher body mass index tend to have lower levels of vitamin D.

\section{Pigmentation}

Murphy et al. (2012) suggested that vitamin D deficiency is increased among men of color, particularly during the winter, among those with a high BMI and without supplementation. Nesby-O'Dell et al. (2002) examined NHANES data from 1988 to 1994 and found that $42.4 \%$ of African American women had low serum vitamin D ( $<37.5 \mathrm{nM})$. This was associated with low consumption of milk or breakfast cereal, no use of vitamin D supplements, season, urban residence, low body mass index, and no use of oral contraceptives.

Coney et al. (2012) found that serum vitamin D levels were significantly lower among African American women compared to white women ( $27.3 \mathrm{nM}$ versus $52.4 \mathrm{nM}$ ) even after adjusting for BMI, percentage body fat, and body weight. In both groups, there were higher levels of serum vitamin D among those with lower BMI and a lower percentage of body fat. Season was associated with significant associations of serum vitamin D, such that in both groups, the level was highest in the summer and lowest in the winter, but still quite low among African American women.

Armas et al. (2007) demonstrated clearly that among Caucasian women that lighter skin color has a greater rate of increase in serum vitamin D with UV exposure. However, after UV treatment, the level of serum vitamin D plateaus or declines to pretreatment levels.

\section{Obesity}

Mai et al. (2012) found lower serum levels associated with higher BMI cross-sectionally in 25616 adults. A random sample of 2460 adults had both BMI and serum vitamin D measured found that those with higher BMI but normal serum vitamin D developed lower vitamin $\mathrm{D}$ over time, suggesting this might be due to the sequestering by body fat. These results could also be due to unmeasured confounding.

Bogh et al. (2011) reported that body surface area was positively correlated with vitamin D status and that skin pigmentation among a group of Danish subjects did not affect vitamin D production (2010). However, Drincic et al. (2012) evaluated different parameters associated with body weight and serum vitamin $\mathrm{D}$ levels and found that dilution in fat mass of vitamin $\mathrm{D}$, whether ingested or synthesized in the skin, was the reason that obese individuals experienced lower vitamin D status.

\section{Sunscreen and other sun protection}

Linos et al. (2012), in an NHANES cross-sectional study, reported that frequent sunscreen use was not associated with vitamin D deficiency. Marks et al. (1995) published similar findings. However, wearing long sleeves and staying in the shade was associated with a small decrement in vitamin D. Whether the small decrement is important in terms of health is unclear. Strong evidence that sunscreen use does not attenuate serum vitamin D comes from XP patients where strict sun protection is not associated with lower vitamin D levels (Hoesl et al., 2010). 


\section{State of knowledge today: uncertain}

To date, there is a great deal of discussion and interest in the way in which vitamin D relates to melanoma as well as other cancers and chronic diseases. It is just as likely that vitamin D levels represent a 'healthy' state in an individual as that they represent a means to achieve a healthy state. Data can be found to support both points of view. This uncertainty can only be remedied by further understanding the biology of melanoma and how vitamin D might interact with other processes to determine whether it is a risk factor or an outcome.

\section{Acknowledgments}

This work was supported by the National Institutes of Health K05 CA13165 to M.B.

\section{References}

Armas LA, Dowell S, Akhter M, Duthuluru S, Huerter C, Hollis BW, Lund R, Heaney RP. Ultraviolet$B$ radiation increases serum 25-hydroxyvitamin D levels: the effect of UVB dose and skin color. J. Am. Acad. Dermatol. 2007; 57:588-593. [PubMed: 17637484]

Asgari MM, Maruti SS, Kushi LH, White E. A cohort study of vitamin D intake and melanoma risk. J. Invest. Dermatol. 2009; 129:1675-1680. [PubMed: 19194478]

Autier P, Dore J-F, Eggermont AMM, Coebergh JW. Epidemiological evidence that UVA radiation is involved in the genesis of cutaneous melanoma. Curr. Opin. Oncol. 2011; 23:189-196. [PubMed: 21192263]

Barroso E, Fernandez LP, Milne RL, et al. Genetic analysis of the vitamin D receptor gene in two epithelial cancers: melanoma and breast cancer case-control studies. BMC Cancer. 2008; 8:385. [PubMed: 19105801]

Berwick M, Armstrong BK, Ben-Porat L, Fine J, Kricker A, Eberle C, Barnhill R. Sun exposure and mortality from melanoma. J. Natl Cancer Inst. 2005; 297:195-199. [PubMed: 15687362]

Bogh MKB, Schmedes AV, Philipsen PA, Thieden E, Wulf HC. Interdependence between body surface area and ultraviolet B dose in vitamin D production: a randomized controlled trial. $\mathrm{Br}$. $\mathrm{J}$. Dermatol. 2011; 164:163-169. [PubMed: 21039402]

Brock K, Huang W-Y, Fraser DR, Ke L, Tseng M, Stolzenberg-Solomon R, Peters U, Ahn U, Purdue $\mathrm{M}$, et al. Low vitamin D status is associated with physical inactivity, obesity and low vitamin D intake in a large US sample of healthy middle-aged men and women. J. Steroid Biochem. Mol. Biol. 2010; 121:462-466. [PubMed: 20399270]

Chatzinasiou F, Lill CM, Kypreou K, Stefanaki I, Nicolaou V, Spyrou G, Evangelou E, Roehr JT, Kidek E, et al. Comprehensive field synopsis and systematic meta-analyses of genetic association studies in cutaneous melanoma. J. Natl Cancer Inst. 2011; 103:1227-1235. [PubMed: 21693730]

Colston KW, Colson MJ, Feldman D. 1,25-hydroxyvitamin D3 and malignant melanoma: the presence of receptors and inhibition of cell growth in culture. Endocrinology. 1981; 108:1083-1086. [PubMed: 6257495]

Coney P, Demers LM, Dodson WC, Kunselman AR, Ladson G, Legro RS. Determination of vitamin $\mathrm{D}$ in relation to body mass index and race in a defined population of black and white women. Int. J. Gynaecol. Obstet. 2012; 119:21-5. [PubMed: 22818533]

Danielsson C, Fehsel K, Polly P, Carlberg C. Differential apoptotic response of human melanoma cells to 1 alpha, 25-dihydroxyvitamin D3 and its analogues. Cell Death Differ. 1998; 5:946-952. [PubMed: 9846181]

Davies JR, Chang YM, Snowden H, Chan M, Leake S, Karpavicius B, Haynes S, Kukalizch K, Randerson-Moor J, et al. The determinants of serum vitamin D levels in participants in a melanoma case-control study living in a temperate climate. Cancer Causes Control. 2011; 22:1471-1482. [PubMed: 21853245]

Demetriou SK, Ona-Vu K, Teichert AE, Cleaver JE, Bikle DD, Oh DH. UV and Vitamin D Receptor mediates DNA repair and is UV inducible in intact epidermis but not in cultured keratinocytes. J. Invest. Dermatol. 2012; 132:2097-2100. [PubMed: 22495177] 
Denzer N, Vogt T, Reichrath J. Vitamin D receptor (VDR) polymorphisms and skin cancer: a systematic review. Dermato-endocrinology. 2011; 3:205-210. [PubMed: 22110781]

Drané P, Compe E, Catez P, Chymkowitch P, Egly JM. Selective regulation of vitamin D receptorresponsive genes by TFIIH. Mol. Cell. 2004; 16:187-197. [PubMed: 15494306]

Drincic AT, Armas LAG, Van Diest EE, Heaney RP. Volumetric dilution, rather than sequestration best explains the low vitamin D status of obesity. Obesity. 2012; 20:1444-1448. [PubMed: 22262154]

Egan KM. Vitamin D and melanoma. Ann. Epidemiol. 2009; 19:455-461. [PubMed: 19282200]

Evans SRT, McGarry Houghton A, Schumaker L, Brenner RV, Buras RR, Davoodi F, Nauta RJ, Shabahag M. Vitamin D receptor and growth inhibition by 1,25-dihydroxyvitamin D3 in human malignant melanoma cell lines. J. Surg. Res. 1996; 61:12-133.

Frampton RJ, Omond SA, Eisman JA. Inhibition of human cancer cell growth by 1,25 dihydroxyvitamin D3 metabolites. Cancer Res. 1983; 43:4443-4447. [PubMed: 6307514]

Gambichler T, Bindsteiner M, Höxtermann S, Kreuter A. Serum 25-hydroxyvitamin D serum levels in a large German cohort of melanoma patients. Br. J. Dermatol. 2012 Epub ahead of print, August 9.

Gandini S, Raimondi S, Gnagnarella P, Doré J-F, Maisonneuve P, Testori A. Vitamin D and skin cancer: a meta-analysis. Eur. J. Cancer. 2009; 45:634-641. [PubMed: 19008093]

Gapska P, Scott RJ, Serrano-Fernandez P, Mirecka A, Rassoud I, Górski B. et al. Vitamin D receptor variants and the malignant melanoma risk: a population based study. Cancer Epidemiol. 2009; 33:103-107. [PubMed: 19679055]

Gerber B, Mathys P, Moser M, Bressoud D, Braun-Fahrländer C. Ultraviolet emission spectra of sunbeds. Photocohem. Photobiol. 2002; 76:664-668.

Giovannucci E, Liu Y, Rimm EB, Hollis BW, Fuchs CS, Stampfer MJ, Willett W. Prospective study of predictors of vitamin D status and cancer incidence and mortality in men. J. Natl Cancer Inst. 2006; 98:451-459. [PubMed: 16595781]

Glerup H, Mikkelsen K, Pulsen L, Hass E, Overbeck S, Charles P, Eriksen EF. Commonly recommended daily intake of vitamin $\mathrm{D}$ is not sufficient if sunlight exposure is limited. J. Intern. Med. 2000; 247:260-268. [PubMed: 10692090]

Halsall JA, Osborne JE, Potter L, Pringle JH, Hutchinson PE. A novel polymorphism in the 1A promoter region of the vitamin $\mathrm{D}$ receptor is associated with altered susceptibility and prognosis in malignant melanoma. Br. J. Cancer. 2004; 91:765-770. [PubMed: 15238985]

Han J, Colditz GA, Hunter DJ. Polymorphisms in the MTHFR and VDR genes and skin cancer risk. Carcinogenesis. 2007; 28:390-397. [PubMed: 16950800]

Hoesl M, Dietz K, Rocken M, Berneburg M. Vitamin D levels of XP-patients under stringent sun protection. Eur J Dermatol. 2010; 20:457-460. [PubMed: 20494856]

Hofmann JN, Yu K, Horst RL, Hayes RB, Purdue MP. Long-term variation in serum 25hydroxyvitamin D concentration among participants in the Prostate, Lung, Colorectal, and Ovarian Cancer Screening Trial. Cancer Epidemiol. Biomarkers Prev. 2010; 19:927-931. [PubMed: 20332255]

Hutchinson PE, Osborne JE, Lear JT, Smith AG, Bowers PW, Morris PN, Jones PW, York C, Strange RC, Fryer AA. Vitamin D receptor polymorphisms are associated with altered prognosis in patients with malignant melanoma. Clin. Cancer Res. 2000; 6:498-504. [PubMed: 10690530]

IARC; International Agency for Research on Cancer Working Group on Artificial Ultraviolet (UV) Light and Skin Cancer. The association of use of sunbeds with cutaneous malignant melanoma and other skin cancers: a systematic review. Int. J. Cancer. 2007; 120:1116-1122. [PubMed: 17131335]

Jorde R, Sneve M, Hutchinson M, Emaus N, Figenschau Y, Grimnes G. Tracking of serum 25hydroxyvitamin D levles during 14 years in a population-based study, and during 12 months in an intervention study. Am. Epidemiol. J. 2010; 171:903-908.

Lazovich D, Vogel RI, Berwick M, Weinstock MA, Anderson KE, Warshaw EM. Indoor tanning and risk of melanoma: a case-control study in a highly exposed population. Cancer Epidemiol.

Biomarkers Prev. 2010; 19:1557-1568. [PubMed: 20507845] 
Li C, Liu Z, Zhang Z, Strom S, Gershenwald JE, Prieto VG, Lee JE, Ross MI, Mansfield PF, et al. Genetic variants of the vitamin D receptor gene alter risk of cutaneous melanoma. J. Invest. Dermatol. 2007; 127:276-280. [PubMed: 16990805]

Linos E, Keiser E, Kanzler M, Sainani KL, Lee W, Vittinghoff E, Chren MM, Tang JY. Sun protective behaviors and vitamin D levels in the US population: NHANES 2003-2006. Cancer Causes Control. 2012; 23:133-140. [PubMed: 22045154]

Lips P, Chapuy MC, Dawson-Hughes B, Pols HA, Holick MF. An international comparison of serum 25-hydroxyvitamin D measurements. Osteoporos. Int. 1999; 9:394-397. [PubMed: 10550457]

Mai X-M, Chen Y, Camargo CA, Langhammer A. Cross-sectional and prospective cohort study of serum 25-hydroxyvitamin D level and obesity in adults. The HUNT study. Am. J. Epidemiol. 2012; 175:1029-1036. [PubMed: 22312120]

Major JM, Kiruthu C, Weinstein SJ, Horst RL, Syder K, Virtamo J, Albanes D. Pre-diagnostic circulating vitamin D and risk of melanoma in men. PLoS ONE. 2012; 7:e35112. [PubMed: 22558121]

Mandelcorn-Monson R, Marrett L, Kricker A, Armstrong BK, Orlow I, Goumas C, Paine S, Rosso S, Thomas N. et al. for the GEM Study. Sun exposure, vitamin D receptor polymorphisms FokI and BsmI and risk of multiple primary melanoma. Cancer Epidemiol. 2011; 35:e105-e110. [PubMed: 21612999]

Marks R, Foley PA, Jolley D, Knight KR, Harrison J, Thompson SC. The effect of regular sunscreen use on vitamin D levels in an Australian population. Arch. Dermatol. 1995; 131:415-421. [PubMed: 7726582]

Mason RS, Pryke AM, Ranson M, Thomas HE, Posen S. Human melanoma cells: functional modulation by calciotropic hormones. J. Invest. Dermatol. 1988; 90:834-840. [PubMed: 2836516]

Millen AE, Tucker MA, Hartge P, Halpern A, Elder DE, Guerry D 4th, Holly EA, Sagebiel RW, Potschman N. Diet and melanoma in a case-control study. Cancer Epidemiol. Biomarkers Prev. 2004; 13:1042-1051. [PubMed: 15184262]

Moan J, Lagunova Z, Cicarma Em Aksnes L, Dahlback A, Grant WB, Porojnicu AC. Sunbeds as vitamin D sources. Photochem. Photobiol. 2009; 85:1474-1479. [PubMed: 19788534]

Mocellin S, Nitti D. Vitamin D receptor polymorphisms and the risk of cutaneous melanoma: a systematic review and meta-analysis. Cancer. 2008; 113:2398-2407. [PubMed: 18816636]

Murphy AB, Kelley B, Nyame YA, Martin IK, Smith DJ, Castaneda L, Zagaja GJ, Hollowell CM, Kittles RA. Predictors of serum vitamin D levels in African American and European American men in Chicago. Am. J. Mens Health. 2012; 6:420-426. [PubMed: 22398989]

Nesby-O'Dell S, Scanlon KS, Cogswell ME, Gillespie C, Hollis BW, Looker AC, Allen C, Doughtertly C, Gunter EW, Bowman BA. Hypovitaminosis D prevalence and determinants among African American and white women of reproductive age: third National Health and Nutrition Examination Survey, 1988-1994. Am. J. Clin. Nutr. 2002; 76:187-192. [PubMed: 12081833]

Newton-Bishop JA, Beswick S, Randerson-Moor J, Chang YM, Affleck P, Elliott F, Chan M, Leake S, Karpavicius B, et al. Serum 25-hydroxyvitamin D3 levels are associated with Breslow thickness at presentation and survival from melanoma. J. Clin. Oncol. 2009; 27:5439-5444. [PubMed: 19770375]

Nilsen LTN, Aalerud TN, Hannevik M, Veierod MB. High UVA exposure from sunbeds. Pigment Cell Melanoma Res. 2012 Epub ahead of print, August 6.

Nowak M, Harrison SL, Buettner PG, Kimlin M, Porter D, Kennedy L, Speare R. Vitamin D status of adults from tropical Australia determined using two different laboratory assays: implications for public health messages. Photochem. Photobiol. 2011; 87:935-943. [PubMed: 21534976]

Nürnberg B, Gräber S, Gärtner B, Geisel J, Pföhler C, Schadendorf D, Tilgen W, Reichrath J. Reduced serum 25-hydroxyvitamin D levels in stage IV melanoma patients. Anticancer Res. 2009; 29:3669-3674. [PubMed: 19667163]

Orlow I, Roy P, Reiner AS, Yoo S, Patel H, Paine S, Armstrong BK, Kricker A, Marrett L. et al. Vitamin D receptor polymorphisms in patients with cutaneous melanoma. Int. J. Cancer. 2012; 130:405-418. [PubMed: 21365644] 
Povey JE, Darakhshan F, Robertson K, Bisset Y, Mekky M, Rees J, Doherty V, Kavanagh G, Anderso $\mathrm{N}$, et al. DNA repair gene polymorphisms and genetic predisposition to cutaneous melanoma. Carcinogenesis. 2007; 28:1087-1093. [PubMed: 17210993]

Randerson-Moor JA, Taylor JC, Elliott F, et al. Vitamin D receptor gene polymorphisms, serum wthydroxyvitamin D levels, and melanoma: UK case-control comparisons and a meta-analysis of published VDR data. Eur. J. Cancer. 2009; 45:3271-3281. [PubMed: 19615888]

Reichrath J, Quering K. No evidence for reduced 25- hydoxyvitamin D serum levels in melanoma patients. Letter.. Cancer Causes Control. 2004; 15:97-98.

Rosso S, Sera F, Segnan N, Zanetti R. Sun exposure prior to diagnosis is associated with improved survival in melanoma patients: results from a long-term follow-up study of Italian patients. Eur. J. Cancer. 2008; 44:1275-1281. [PubMed: 18406602]

Santonocito C, Capizzi R, Concolino P, Lavieri MM, Paradisi A, Gentileschi S, Torti E, Rutella S, Rocchetti S, et al. Association between cutaneous melanoma, Breslow thickness and vitamin D receptor BsmI polymorphism. Br. J. Dermatol. 2007; 156:277-282. [PubMed: 17223867]

Schäfer A, Emmert S, Kruppa J, Schubert S, Tzvetkov M, Mössner R, Reich K, Berking C, Volkenandt M, et al. No association of vitamin D metabolism-related polymorphisms and melanoma risk as well as melanoma prognosis: a case-control study. Arch. Dermatol. Res. 2012; 304:353-361. [PubMed: 22576141]

Sempos CT, Vesper HW, Phinney KW, Thienpont LM, Coates PM. Vitamin D status as an international issue: national surveys and the problem of standardization. Scand. J. Clin. Lab. Invest. Suppl. 2012; 243:32-40. [PubMed: 22536760]

Shipman AR, Clark AB, Levell NJ. Sunnier European countries have lower melanoma mortality. Clin. Exp. Dermatol. 2011; 36:544-547. [PubMed: 21418285]

Tang JY, Fu T, LeBlanc E, Manson JAE, Feldman D, Linos E, Vitolins MZ, Zeitouni NC, Larson J, Stefanick ML. Calcium plus vitamin D supplementation and the risk of nonmelanoma and melanoma skin cancer: post hoc analyses of the women's health initiative randomized controlled trial. J. Clin. Oncol. 2011; 29:30078-30084.

Thieden E, Philipsen PA, Wulf HC. Ultraviolet radiation exposure pattern in winter compared with summer based on time-stamped personal dosimeter readings. Br. J. Dermatol. 2006; 154:133-138. [PubMed: 16403106]

Thieden E, Jorgensen H, Jorgensen N, Philipsen P, Wulf HC. Sunbed radiation provokes skin vitamin D synthesis. Photochem. Photobiol. 2008; 84:1487-1492. [PubMed: 18513233]

Vinceti M, Malagoli C, Fiorentini C, Longo C, Crespi CM, Albertini G, Ricci C, Lanzoni A, Reggiani $\mathrm{M}$, et al. Inverse association between dietary vitamin $\mathrm{D}$ and risk of cutaneous melanoma in a northern Italy population. Nutr. Cancer. 2011; 63:506-513. [PubMed: 21541899]

Wang SQ, Setlow R, Berwick M, Polsky D, Marghoob AA, Kopf AW, Bart RS. Ultraviolet A and melanoma: a review. J. Am. Acad. Dermatol. 2001; 44:837-846. [PubMed: 11312434]

Ward KA, Lazovich DA, Hordinsky MK. Germline melanoma susceptibility and prognostic genes: a review of the literature. J. Am. Acad. Dermatol. 2012 Epub ahead of print, May 12.

Weinstock MA, Stampfer MJ, Lew RA, Willett WC, Sober AJ. Case-control study of melanoma and dietary vitamin D: implications for advocacy of sun protection and sunscreen use. J. Invest. Dermatol. 1992; 98:809-811. [PubMed: 1569330]

Yang L, Lof M, Veierod MB, Sandin S, Adami H-O, Weiderpass E. Ultraviolet exposure and mortality among women in Sweden. Cancer Epidemiol. Biomarkers Prev. 2011; 20:683-690. [PubMed: 21297041]

Yudoh K, Matsuno H, Kimura T. 1alpha,25-dihydroxyvitamin D3 inhibits invasiveness through the extracellular matrix and in vivo pulmonary metastasis of B16 mouse melanoma. J. Lab. Clin. Med. 1999; 133:120-128. [PubMed: 9989763] 
Table 1

Published studies of the most common vitamin D receptor polymorphisms

\begin{tabular}{|c|c|c|c|c|c|c|c|c|}
\hline Variant & Author, year & Country & $\begin{array}{l}\text { Study } \\
\text { design }\end{array}$ & $\begin{array}{l}\text { Source } \\
\text { of } \\
\text { controls }\end{array}$ & $\begin{array}{l}\text { Total } \\
\text { cases }\end{array}$ & RR 95\% CI & $\begin{array}{l}\text { Minor } \\
\text { allele }\end{array}$ & $\begin{array}{l}\text { Referent } \\
\text { allele }\end{array}$ \\
\hline FokI rs 2228570 & Hutchinson, 2000 & UK & Case-control & Hospital & 316 & $1.90(0.93,3.89)$ & $\mathrm{ff}$ & $\mathrm{FF}$ \\
\hline \multirow[t]{5}{*}{ rs10735810) } & Han, 2007 & USA & $\begin{array}{l}\text { Nested } \\
\text { case-control }\end{array}$ & Cohort & 215 & $1.40(0.86,2.27)$ & $\mathrm{ff}$ & $\mathrm{FF}$ \\
\hline & Gapska, 2009 & Poland & Case-control & Population & 763 & $0.99(0.8,1.3)$ & $\mathrm{ff}$ & $\mathrm{Ff}^{\mathrm{a}}$ \\
\hline & Randerson-Moor, 2009 & UK & Case-control \#1 & Population & 1028 & $1.03(0.73,1.47)$ & $\mathrm{Ff}$ & $\mathrm{FF}$ \\
\hline & Randerson-Moor, 2009 & UK & Case-control \#2 & Population & 299 & $1.88(1.25,2.82)$ & $\mathrm{Ff}$ & $\mathrm{FF}$ \\
\hline & Orlow, 2012 & $\begin{array}{l}\text { US, } \\
\text { Canada, Italy, Australia }\end{array}$ & Case-control & Population & 1207 & $1.05(0.83,1.33)$ & $\mathrm{ff}$ & $\mathrm{FF}$ \\
\hline \multirow{5}{*}{ rs 1544410} & Li, 2007 & USA & Case-control & Hospital & 805 & $0.78(0.58,1.05)$ & $\mathrm{BB}$ & $\mathrm{bb}$ \\
\hline & Gapska, 2009 & Poland & Case-control & Population & 763 & $0.97(0.7, .3)$ & $\mathrm{BB}$ & $\mathrm{Bb}^{a}$ \\
\hline & Randerson-Moor, 2009 & UK & Case-control \#1 & Population & 299 & $1.00(0.71,1.41)$ & $\mathrm{BB}$ & $\mathrm{bb}$ \\
\hline & Randerson-Moor, 2009 & UK & Case-control \#2 & Population & 299 & $0.69(0.45,1.06)$ & $\mathrm{BB}$ & $\mathrm{bb}$ \\
\hline & Orlow, 2012 & $\begin{array}{l}\text { US, } \\
\text { Canada, } \\
\text { Italy, } \\
\text { Australia }\end{array}$ & Case-control & Population & 1207 & $1.30(1.04,1.63)$ & $\mathrm{BB}$ & $\mathrm{bb}$ \\
\hline TaqI & Hutchinson, 2000 & UK & Case-control & Hospital & 316 & $1.11(0.56,2.19)$ & $\mathrm{tt}$ & $\mathrm{TT}$ \\
\hline \multirow[t]{2}{*}{ rs731236 } & $\mathrm{Li}, 2007$ & USA & Case-control & Hospital & 805 & $0.80(0.62,1.04)$ & $\mathrm{tt}$ & $\mathrm{TT}$ \\
\hline & Schäfer, 2012 & Germany & Case-control & Hospital & 305 & $0.99(0.65,1.50)$ & GG & $\mathrm{TT}$ \\
\hline A-1012G Also & Halsall, 2004 & UK & Case-control & Hospital & 174 & $0.40(0.19,0.85)$ & GG & $\mathrm{AA}$ \\
\hline known as & Povey, 2007 & UK & Case-control & Hospital & 596 & $0.78(0.57,1.08)$ & GG & AA \\
\hline EcoRV & Santonocito, 2007 & Italy & Case-control & Population & 101 & $1.42(0.55,3.68)$ & GG & AA \\
\hline \multirow[t]{3}{*}{ rs4516035 } & Barroso, 2008 & Spain & Case-control & Universities & 283 & $1.79(0.91,3.53)$ & GG & AA \\
\hline & Gapska, 2009 & Poland & Case-control & Population & 763 & $1.04(0.9,1.4)$ & GG & $\mathrm{GA}^{a}$ \\
\hline & Orlow, 2012 & $\begin{array}{l}\text { US, } \\
\text { Canada, } \\
\text { Italy, } \\
\text { Australia }\end{array}$ & Case-control & Population & 1207 & $1.25(1.01,1.55)$ & GG & AA \\
\hline $\mathrm{Cdx}$ & Han, 2007 & USA & Nested & Cohort & 215 & $0.56(0.21,1.46)$ & AA & GG \\
\hline
\end{tabular}

Pigment Cell Melanoma Res. Author manuscript; available in PMC 2014 January 01. 


\begin{tabular}{|c|c|c|c|c|c|c|c|c|}
\hline Variant & Author, year & Country & $\begin{array}{l}\text { Study } \\
\text { design }\end{array}$ & $\begin{array}{l}\text { Source } \\
\text { of } \\
\text { controls }\end{array}$ & $\begin{array}{l}\text { Total } \\
\text { cases }\end{array}$ & RR 95\% CI & $\begin{array}{l}\text { Minor } \\
\text { allele }\end{array}$ & $\begin{array}{l}\text { Referent } \\
\text { allele }\end{array}$ \\
\hline \multirow[t]{3}{*}{2 rs11568820 } & & & case-control & & & & & \\
\hline & Randerson-Moor, 2009 & UK & Case-control \#2 & Population & 299 & $0.99(0.54,1.84)$ & AA & GG \\
\hline & Orlow, 2012 & $\begin{array}{l}\text { US, } \\
\text { Canada, } \\
\text { Italy, } \\
\text { Australia }\end{array}$ & Case-control & Population & 1207 & $1.18(0.79,1.75)$ & AA & GG \\
\hline
\end{tabular}

${ }^{a}$ Gapska used heterozygotes as the baseline reference group. 